\title{
Internet Banking in Nepal: Use and Challenges
}

\author{
Jyoti Raj Khatri \\ Research Fellow, Think Tank Foundation, Kathmandu, Nepal \\ Email: ttfnepal@gmail.com \\ Kshitiz Upadhyay-Dhungel \\ Director - Research and Planning, Think Tank Foundation
}

\begin{abstract}
With the advancement in the technology, one of the latest technologies adopted by bank is the electronic banking (or e-banking). Internet banking, one of the channels of e-banking, helps bank customers to perform their financial transactions electronically over the internet through their personal computer or laptop at a time convenient to them, without having to be restricted to regular bank operating hours. With the establishment of Nepal Bank Limited in 1937, banking sector and its customers had to wait for 65 years to use the internet banking service in Nepal (around 2002). But still internet banking is not yet popular among the customers in Nepal. Hence, this research focuses on the usage of internet banking and its challenges in Nepal.
\end{abstract}

Data collection was done in two phases: first from the banks and second from the customers. Two sets of self-designed structured questionnaires were developed to collect data one from banks and other from customers.

The results highlighted some important aspects regarding e-banking in Nepal. The findings suggested that the majority of the account holders use internet, have some knowledge about the internet banking provided by their bank, but they have not developed the habit of utilizing this facility. Awareness about internet banking and its benefits and security were identified as the major reason behind less utilization of internet banking among the customers. Whereas customer's education levels, their knowledge about the computer and internet, electricity problem and theft of password, and internet infrastructure in the country were identified as major challenges faced by the bank regarding the development of their online facilities.

KEYWORDS: E-banking, Internet Banking, Financial Transactions, IT Security, Internet Infrastructure

\section{INTRODUCTION}

With the advancement in information and communication technology, banking sector are subjected to this technological change and are embracing new technology-based service options to remain competitive. One of the latest technologies adopted by bank is electronic banking or e-banking. The term electronic banking refers to process of performing various banking activities by the use of electronic channels through telephone, mobile phone, internet, etc (Sharma, 2011). 
In 2008, Bill Gates announced that "banking is essential, banks are not" which reflect that there is a need to adopt e-banking in order to replace the traditional bank branch (Baten and Kamil, 2010). Today's banks and financial institutions have moved to e-banking in their efforts to cut costs while maintaining reliable customer services (Kolodinsky and Hogarth, 2001). E-banking, which consists of uses of different technologies such as Automated Teller Machine (ATM), Point of Sales (PoS), Telephone Banking (Tele-Banking), Internet Banking, Mobile Banking, etc have created new ways of handling banking transactions and are also important for the banks in order to have the long-term survival (Burnham, 1996). Traditional method of banking are limited by the time, space, and resources but through ebanking, banking services can be obtained outside of the normal opening hours, that is, one can get access to bank services twenty four hours a day and seven days a week (Rubino, 2000). Services like balance inquiry, account information, funds transfer, paying bills electronically, applying for a loan, viewing the image of their cheque and deposit slip, etc are offered through e-banking (Turban et al 2004). Although all the customers get benefit from these services, especially it is appealing to the customers who have hard time keeping track of their finances (Deitel et al., 2001).

Among the different channels of e-banking, internet banking is increasingly becoming popular because of convenience and flexibility. Under internet banking customers perform their banking activities electronically over the internet through their personal computer or laptop at a time convenient to them, without having to be restricted to regular branch operating hours. Mols (1999) acknowledged that the internet banking is an innovative distribution channel that offers less waiting time and a higher spatial convenience than traditional branch banking with significantly lower cost structure than traditional delivery channels. Internet banking reduces not only operational cost to the bank but also leads to higher levels of customer satisfaction and retention. As a result, internet banking is very attractive to banks and customers, who are now adopting new technologies.

Internet banking is defined as "the provision of retail and small value banking products and services through electronic channels. Such products and services include deposit-taking, lending, account management, the provision of financial advice, electronic bill payment, and the provision of other electronic payment products and services such as electronic money (Basel, 1998)".

With the establishment of Nepal Bank Ltd. in 1937, the first bank to start banking in Nepal, it took nearly 53 years for the introduction of credit cards by the Nabil Bank Ltd. in early 1990s. As for the development of e-banking in Nepal, Himalayan Bank Ltd. stood in a front row with the introduction of Automated Teller Machine (1995) and Tele-banking. After the establishment of first bank, Banking sector as well as bank costumers have to wait nearly about 65 years for internet banking, and the Kumari Bank Ltd. was the first to start the internet banking in Nepal in 2002 ( Mishra, 2008). After ten years of introduction of internet banking, it is still not popular in Nepal, people still rely on traditional ways of banking. Although the major cities like Kathmandu, Pokhara, Biratnagar have good internet facilities and 
majority of the bank provides the internet banking in urban cities but still internet banking is in its early stage and is not utilized by most of the bank customers. Study shows that there are about 200,000 internet users in Nepal, out of which $50 \%$ user are inside Kathmandu valley. However, only about 3000 (1.5\%) internet user is using the internet banking. One of the study have found that in terms of ebanking, ATM services is adapted by most of the banks in Nepal, while mobile banking getting the popularity but internet (computer-based) banking is still not available (Amrit, 2007).

Therefore as a service provider, banks should know the success factors that influence the customers' tendency to use internet banking, as a possible banking channel. They should also know the consumer's perception about the internet banking. Factors affecting consumer acceptance and adoption of internet banking have been investigated in many countries but research in this regard is limited in Nepal and there is still a gap, which this study wishes to fulfill. This study is conducted to know the types of facilities provided under internet banking service (IBS), customer knowledge about the service, and difficulties faced by banks while providing the service.

\section{Objectives}

1. To understand current status and trends of use of internet banking services;

2. To analyze facilities provided by the bank under internet banking service facility;

3. To identify the challenges faced by banks concerning the development of internet banking services;

4. To find out the level of awareness about the internet banking among the bank customers.

\section{METHODOLOGY}

\section{Research design and data collection}

This study is descriptive type and data collection was done in two phases. Two sets of different questionnaires were developed one for each phase. During first phase information about the internet banking, facilities or services under internet banking, problem in providing such facilities, etc were collected from the banks that are providing the internet banking facilities. For this five banks were selected and information was obtained through the self-designed questionnaire distributed to the bankers.

In second phase, data were collected from the bank customers through selfdesigned, structured questionnaire. The questionnaire was distributed to 100 customers. Out of the 100 Questionnaires distributed, only 60\% were returned / responded back.

For both the cases, convenience, non-probability sampling was used due to limitation of resources and time. Also in Nepalese context, it is difficult to find the respondent because of their disinterest and not willing to share genuine information. Data management and analysis were done by using SPSS program and Microsoft Excel program. 


\section{RESULTS}

\section{Respondent's internet banking using behavior}

The characteristics of the respondents are presented in Table (1). Out of 60 samples collected, about $65 \%$ were male and $35 \%$ were female. On the other hand, $92 \%$ were Hindu and $8 \%$ were Buddhist. Besides, $80 \%$ of samples hold bachelors or higher university degree. In terms of occupation about $31.7 \%$ of them were found engaged in the private sector with profession like doctor, engineer, and teacher and about $17 \%$ of the respondents were student. Average age of the respondent was 31.82 years.

Table 1: Characteristics of the respondents

\begin{tabular}{llrr}
\hline Variable & & Frequency & Percent \\
\hline Sex & Female & 21 & 35 \\
\multirow{4}{*}{ Religion } & Male & 39 & 65 \\
& Hindu & 55 & 91.7 \\
& Buddhist & 5 & 8.3 \\
\multirow{5}{*}{ Occupation } & Secondary & 2 & 3.3 \\
& Higher secondary/Intermediate & 10 & 16.7 \\
& Bachelors or more & 48 & 80.0 \\
& Business man & 10 & 16.7 \\
& Government service & 7 & 11.7 \\
& Bank & 5 & 8.3 \\
& Private sector & 19 & 31.7 \\
& Student & 10 & 16.7 \\
& NGO/INGO & 2 & 3.3 \\
& Housewife & 7 & 11.7 \\
\hline
\end{tabular}

Figure (1) reveals the frequency of the respondents knowing about the internet banking or who have at least heard about the internet banking. Around $85 \%$ of the respondents in our sample have heard about the internet banking, out of which around $69 \%$ were the male respondents. Among those who have not heard about the internet banking most of them were the housewives (44.4\%).

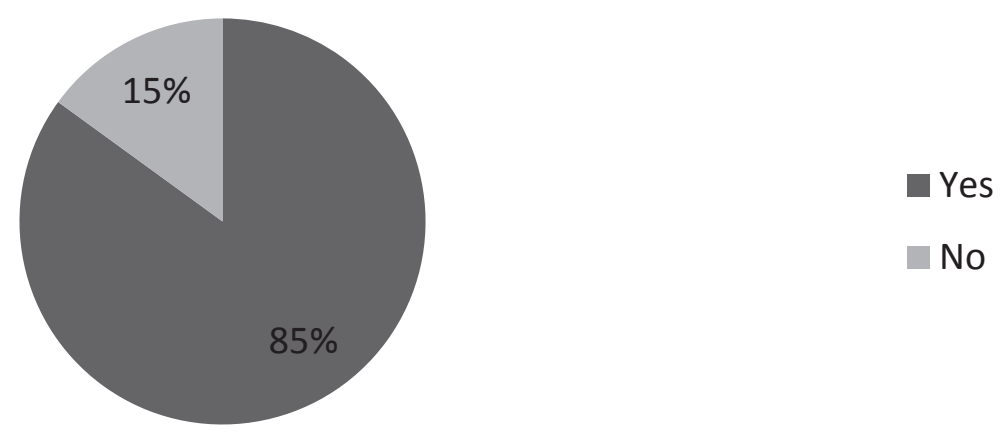

Figure 1: Knowledge of respondents about internet banking. 
Figure (2) reveals the source of respondents' knowledge about internet banking. Of $85 \%$ who have heard about the internet banking, $47 \%$ have heard from the media (television, radio, or newspaper), and $41 \%$ have got the information from the bank itself. Similarly, $10 \%$ of the respondents have got the information from other users of internet banking.

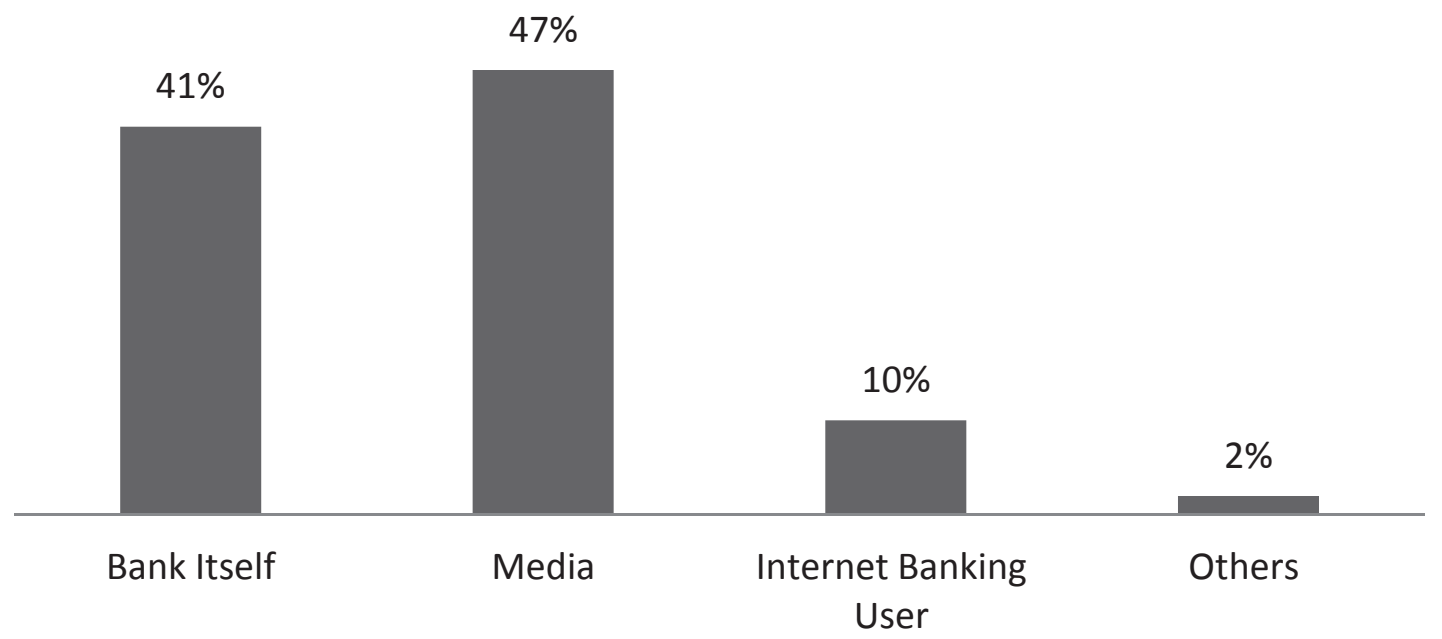

Figure 2: Sources of knowledge about internet banking

Figure (3) depicts the internet using behavior of the sampled respondents. As per the figure, approximately $92 \%$ of the respondent, which is in fact a big number of users, uses the internet either in their work place or at home. This shows the great scope for increasing the use of internet banking, at least to the cities where internet facility is abundant.

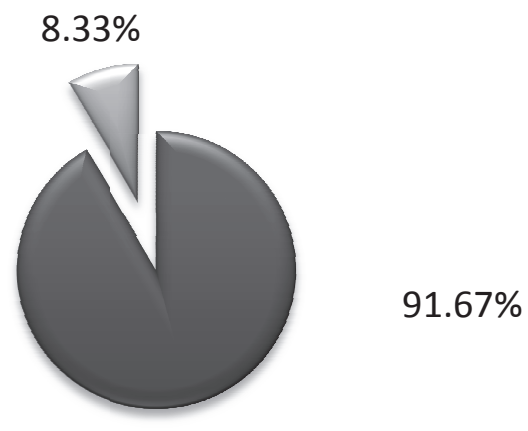

$\square$ Using Internet $\quad$ Not using Internet

\section{Figure 3: Respondents internet using behavior}

Figure (4) exhibits percentage of respondent with the knowledge about the internet banking service provided by their bank. A look at the figure clearly suggests that majority of the respondents $(65 \%)$ know that their bank provide the internet banking facilities but around $33 \%$ of the respondents do not know or have no knowledge whether their bank provide the internet banking service or not. Less than $2 \%$ have said that their bank does not provide the internet banking service. 
Similarly, $57 \%$ of female respondents do not have any idea about the internet banking service provided by their bank compared to $20 \%$ of male respondents.

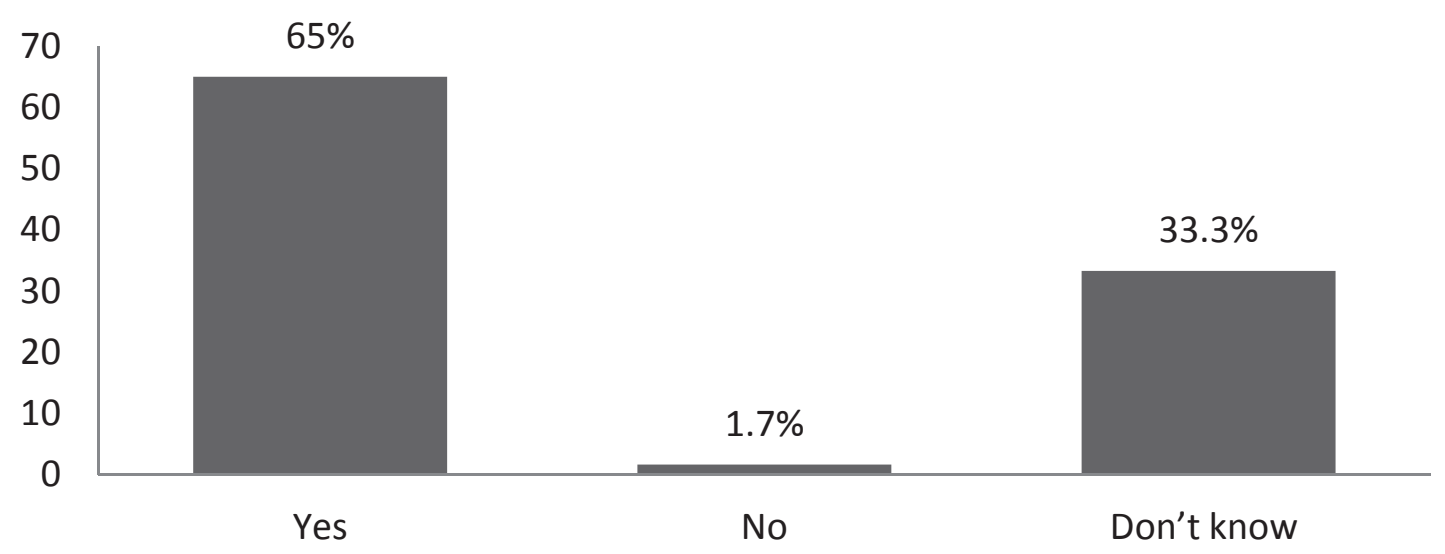

Figure 4: Knowledge about internet banking service provide by their bank

Figure (5) gives the clear picture about the respondent's knowledge about their bank's website. Only 22 of the respondents (about 37\%) out of total respondents have visited their bank website and $63 \%$ have stated that they haven't visited their bank website. Approximately $44 \%$ of the respondents who know that their bank provide the internet banking service have not visited their bank website. This figure also shows that all the housewives and those working in government service and NGO/INGO, included in our study, have not visited their bank's website. This may show the customer's negligence and may hint towards the need of financial literacy.

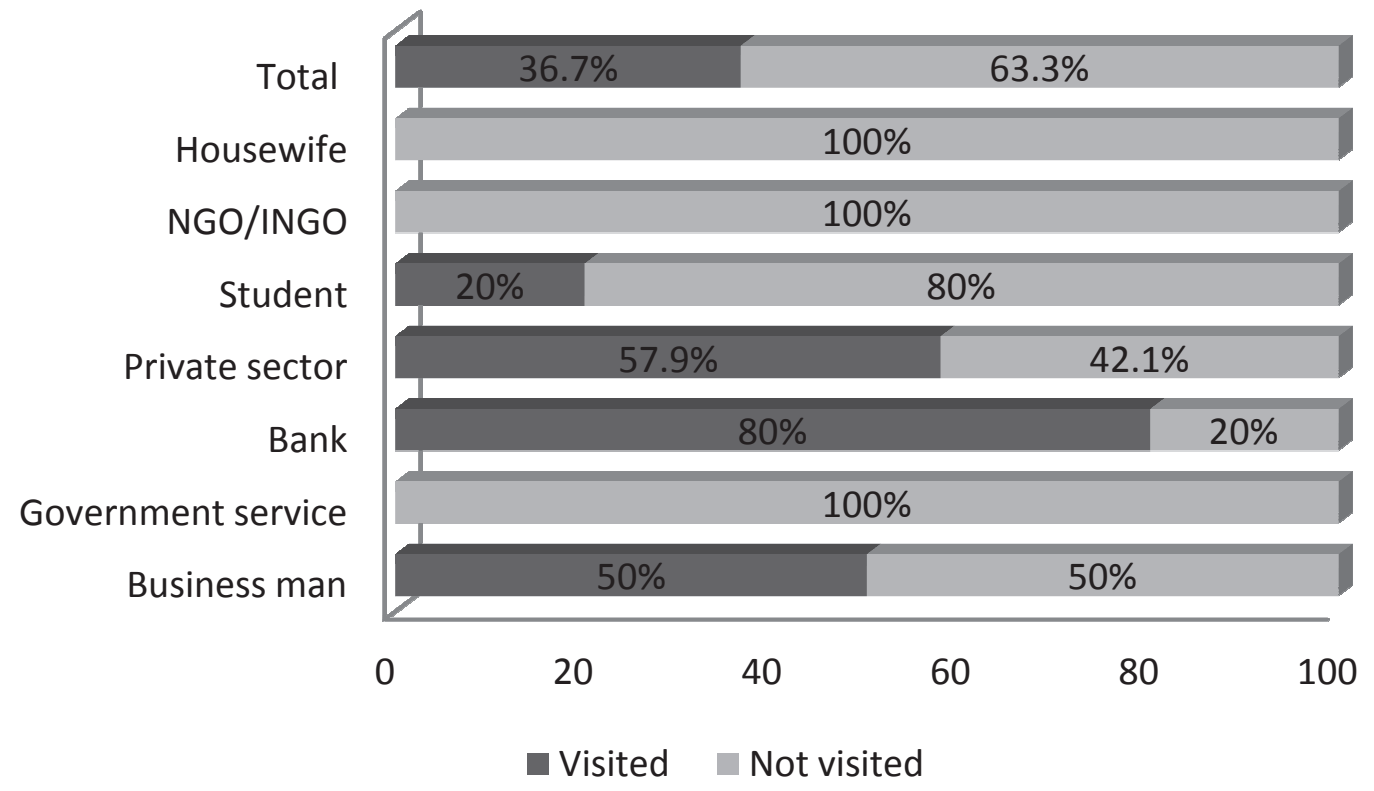

Figure 5: Distribution of the respondents visiting and not visiting their bank website 
The respondent's behavior of using the internet banking services was also explored (Table 2). Most importantly this study finds out that using the internet for banking purpose or utilizing the internet banking facilities is not well developed among the customers. In our study, only $37 \%$ of the respondents have said that they have used or are currently using the internet for the banking purpose. Nearly about twothird of the respondents in our study do not use the internet banking services. Those who have used the internet banking mostly said that they have used for the personal purpose and no one was recorded for the official purpose.

Also, when we look for the regularity of using the service we found that very few people use it regularly. More than half of those who use the service even do not use it once in a month. Hence there is a scope for increasing the use of the services, especially among the customers who are using it less regularly.

Table 2: Respondents behavior of using the internet banking service

\begin{tabular}{lrr}
\hline Categories & Frequency & Percentage \\
\hline Respondents using internet banking service. & 22 & 37 \\
Regularity of using the internet banking service & & 9 \\
Daily & 2 & 22 \\
Weekly & 5 & 13 \\
Monthly & 3 & 54 \\
Others & 12 & \\
Purpose of using the internet banking service & & 96 \\
Personal & 21 & 4 \\
Business Official & 1 & \\
\hline
\end{tabular}

From the figure (Figure 6), it is evident that out of those who have ever used or are currently using the internet banking, around 55\% have utilized this service from the country and rest $45 \%$ from outside Nepal indicating that users also prefer to use the internet banking service when they are out of the country. This increases the scope of development of e-banking services to cater foreign migrant Nepalese (short or long term).

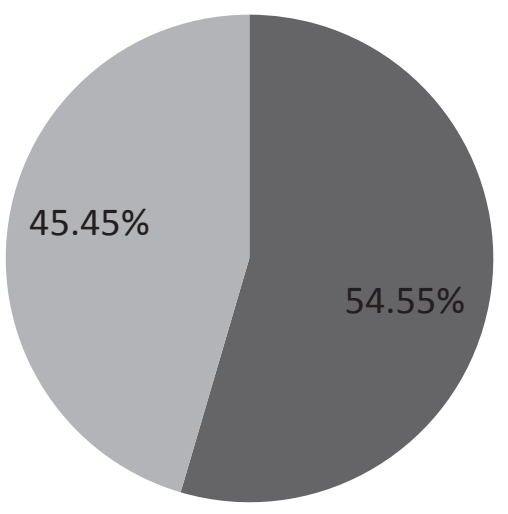

Within Nepal

- Outside Nepal

Figure 6: Distribution of internet banking users according to place of use 
Table (3) reveals the different kinds of activities performed by the respondents under the internet banking facilities provided by their bank. The table shows that majority of the internet banking adaptors have utilized this facility for checking their account information; requesting, downloading, and printing the account statement; and paying the utility bills or bills of purchased goods. Whereas, only a few number of the users have performed the account transfer facilities. Account information facility has been used by the $100 \%$ of the respondent using internet banking facility, followed by statement request and paying the utility bills which account $86 \%$ and $63 \%$, respectively.

\section{Table 3: Activities performed by the internet banking users}

\begin{tabular}{lrr}
\hline Activities performed & Frequency & Percentage \\
\hline Account Information & 22 & 100 \\
Request for Statement(View) & 19 & 86 \\
Download and print statements & 12 & 54 \\
Within same bank Accounts & 8 & 36 \\
To other Bank Accounts within Nepal & 3 & 13 \\
Paying utility bills & & \\
(Telephone, school/college, electricity, etc) & 14 & 63 \\
\hline
\end{tabular}

Similarly from the figure (Figure 7), it is evident that only one of the respondents out of all, using one or more of the internet banking services, has performed all the activities listed in Table (3) or provided by its bank. Around 36\% of users have performed four different kinds of activities under internet banking service, while $18 \%$ of users have only performed two kinds of activities. Hence on an average the users are conducting 3.5 different kinds of banking activities through their bank website by using the internet banking service provided by the bank.

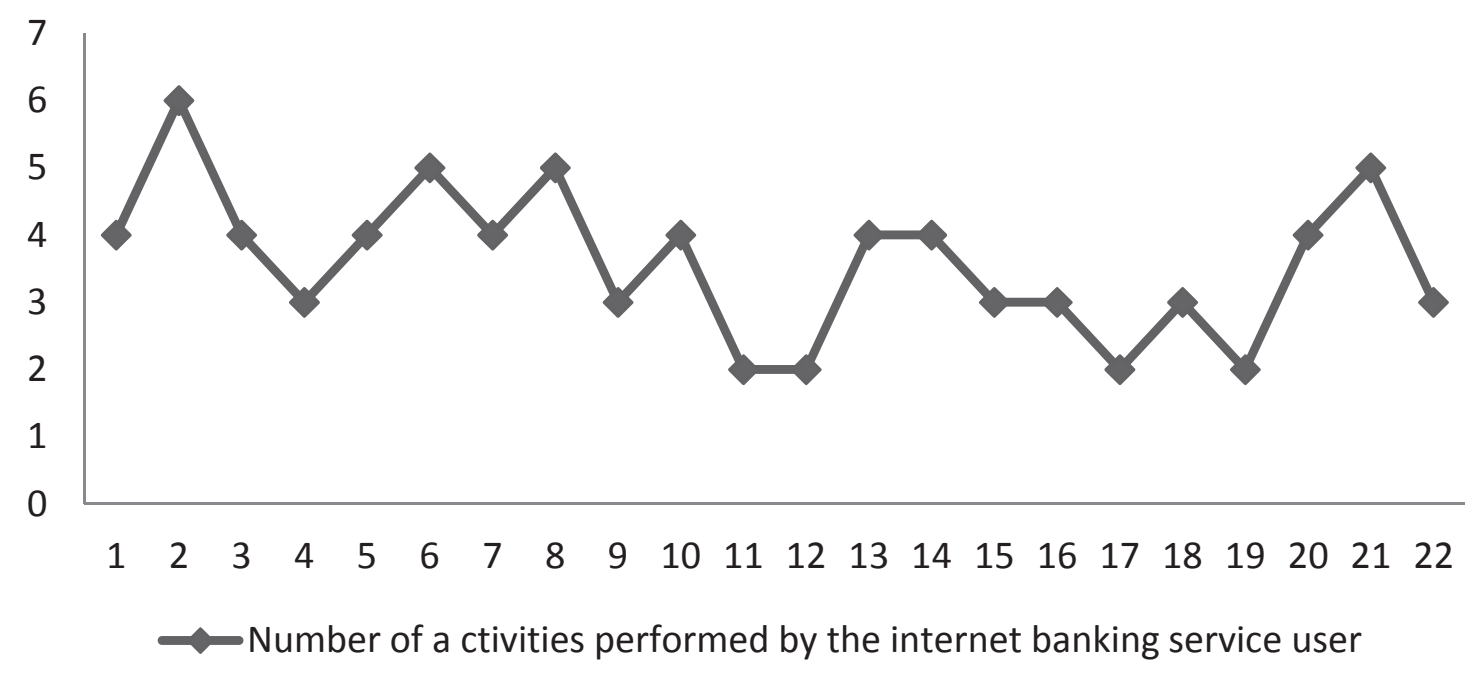

Figure 7: Number of activities performed by the internet banking service users 
For those who have used the internet banking facilities their perception were taken with regard to the use of internet banking. Most of the respondents agreed that internet banking have enabled them to accomplish banking activities more quickly, feel secure, and efficient for conducting the financial activities. They feel that internet banking website of their bank is trustworthy, clear, and understandable and keeps the customers satisfaction in mind. They have pointed out that the security of internet banking is important. Generally, those who have used or are using the internet banking services were satisfied from facilities and have positive attitude towards it.

Figure (8) presents the different factors emphasized by the respondents for not utilizing the internet banking services. In this study, around 38 respondents were found not using the internet banking facilities. They are asked the reasons for not using the internet banking. Lack of information about internet banking facility was identified as a major reason behind not using this facility, as $74 \%$ of respondents have chosen this answer. Similarly familiarity about the online banking technology $(66 \%)$, electricity problem (63\%), and irregular banking activities were other major reasons behind less utilization of internet banking service in Nepal. Respondents were also concerned about the security, speed and reliability of the technology, and the banking website related to the online banking.

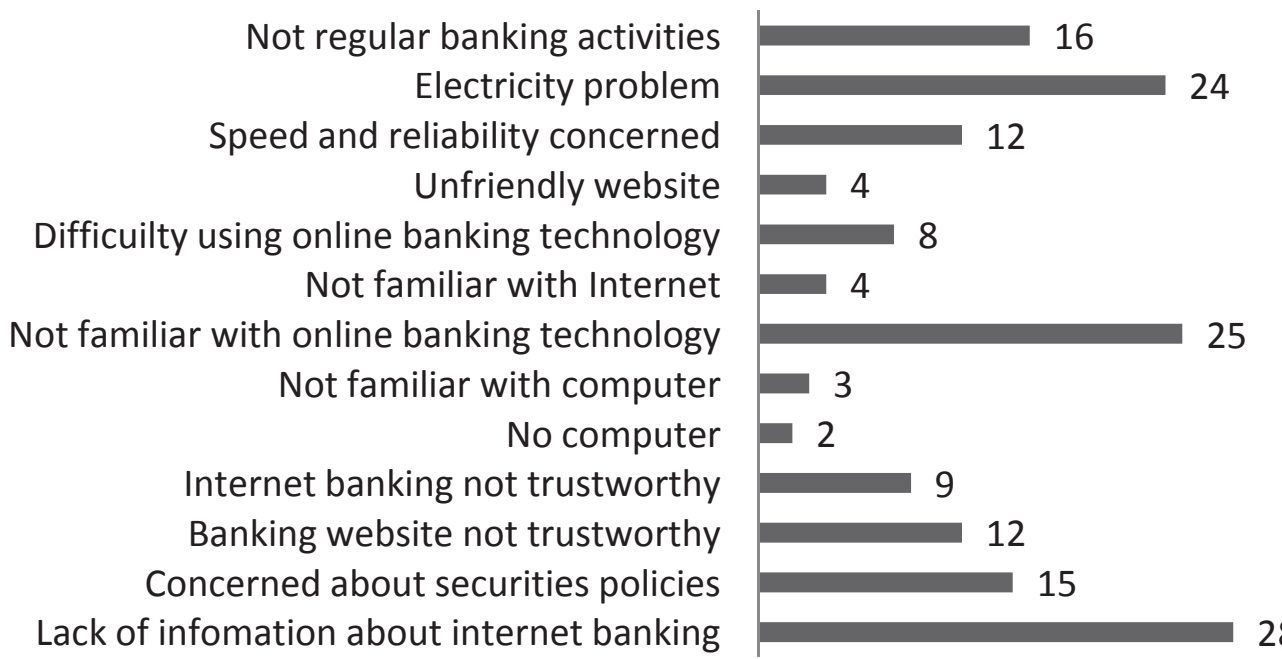

Figure 8: Factors for not utilizing the internet banking service

\section{Service provided by bank and challenges}

Data were collected from the five banks and financial institutions (BFIs) out of which four of them are commercial banks (CB) and one is a finance company (FC).

In the table (Table 4), we can see that all of the five BFIs which we have included in our study are providing the internet banking services. When we looked for the 
types of services they provide under internet banking we found that all of them provide account information, request for statement (view), and download and printing of statement services. While the fund transfers to other bank account, personal updates, credit card limit increase requests, and use of internet banking for investment purpose were not provided. Some of the distinct features of these BFIs were: Bank of Kathmandu Ltd. (BOK) provides the service of check book request; Nabil Bank Ltd. (NABIL) provides the service of credit card transaction review; NABIL and Bank of Asia Ltd. (BOA, currently merged with NIC Bank Ltd. to form NIC Asia Bank Ltd.) provides the status of inward remittance service; NABIL and BOK provides the facility of credit card payments; and NABIL, BOA, and BOK have the facility of using the internet banking for utility purpose. It seems that that Sunrise Bank Ltd. (SRBL) is only the bank that does not include the service of fund transfer within the same bank account. Being a finance company Narayani National Finance Ltd. (NNFL) has provided only limited activities under its internet banking services.

Table 4: Services provided by the bank under internet banking

\begin{tabular}{lccccc}
\hline Bank & NABIL & BOA & SRBL & BOK & NNFL \\
\hline Bank type & CB & CB & CB & CB & FC \\
Office type & B & B & B & H & B \\
IBS provided & Y & Y & Y & Y & Y \\
Account Services & & & & & \\
Account Information & Y & Y & Y & Y & Y \\
Request for Statement(View) & Y & Y & Y & Y & Y \\
Download and print statements & Y & Y & Y & Y & Y \\
Cheque Book Request & N & N & N & Y & N \\
Status of Inward Remittance & Y & Y & N & N & N \\
Fund Transfer & & & & & \\
Within same bank Accounts & Y & Y & N & Y & Y \\
To other Bank Accounts within Nepal & N & N & N & N & N \\
Personal Updates & & & & & \\
Change Contact Details & $\mathrm{N}$ & $\mathrm{N}$ & $\mathrm{N}$ & $\mathrm{N}$ & $\mathrm{N}$ \\
Change Address Information & $\mathrm{N}$ & $\mathrm{N}$ & $\mathrm{N}$ & $\mathrm{N}$ & $\mathrm{N}$ \\
Credit Card Management & & & & & \\
Credit Card Transaction Review & $\mathrm{Y}$ & $\mathrm{N}$ & $\mathrm{N}$ & $\mathrm{N}$ & $\mathrm{N}$ \\
Credit Card Payments & $\mathrm{Y}$ & $\mathrm{N}$ & $\mathrm{N}$ & $\mathrm{Y}$ & $\mathrm{N}$ \\
Credit Card Limit Increase Request & $\mathrm{N}$ & $\mathrm{N}$ & $\mathrm{N}$ & $\mathrm{N}$ & $\mathrm{N}$ \\
Utility Purpose & & & & & \\
Paying utility bills (Telephone charges, & $\mathrm{Y}$ & $\mathrm{Y}$ & $\mathrm{N}$ & $\mathrm{Y}$ & $\mathrm{N}$ \\
school/college fees, electricity etc) & & & & & \\
Investment purpose & $\mathrm{N}$ & $\mathrm{N}$ & $\mathrm{N}$ & $\mathrm{N}$ & $\mathrm{N}$ \\
\hline B & & &
\end{tabular}

B = branch office; $\mathrm{H}=$ head office; $\mathrm{Y}$ : = yes; $\mathbf{N}=$ no

When we looked for the requirements for using the internet banking services our result (Table 5) shows that the entire BFIs in our study provide the IBS to all types of customers and the services was not limited to some special customers. However, some BFIs may include all customers in IBS (or provide form to all new account openers) or in most cases customers themselves have to request for including IBS in their account and fill a different form. All banks provide the 24 hours internet banking services (365 days, that is round the year). 
Customers have to register before using this facility in all the case. But in the case of NABIL, BOA, and SRBL, they do not require any registration fee, while BOK and NNFL charges less than five hundred rupees as a registration fee. Similarly, customers of NABIL and SRBL do not have to pay any charges for using the IBS, whereas all other three institutions charge their customers for using IBS on a yearly basis except BOK which charges customers on the basis of volume of transaction.

Table 5: Requirements for using the internet banking services

\begin{tabular}{|l|l|l|l|l|l|}
\hline Requirements/Banks & NABIL & BOA & SRBL & BOK & NNFL \\
\hline Type of customers & All & All & All & All & All \\
\hline Year launched & $>5$ yrs & NA & NA & NA & NA \\
\hline Time allocate for IBS to customers & No & No & No & No & No \\
\hline IBS hour/time & $24 \mathrm{Hrs}$ & $24 \mathrm{Hrs}$ & $24 \mathrm{Hrs}$ & $24 \mathrm{Hrs}$ & $24 \mathrm{Hrs}$ \\
\hline Access to IBS on opening account & No & Yes & No & No & No \\
\hline Registration need by customers & Yes & Yes & Yes & Yes & Yes \\
\hline Registration fee for using IBS & No & No & No & $<$ NPR 500 & $<$ NPR 500 \\
\hline Charges for using IBS & No & $<$ NPR 500 & No & $<$ NPR 500 & $<$ NPR 500 \\
\hline Method of payment & - & Yearly & - & DoT & Yearly \\
\hline
\end{tabular}

Yrs: years; NA = not available, cannot say the exact date; Hrs = hours; NPR = Nepalese Rupees; DoT = depending on transaction volume

Figure (9) presents the challenging factors that the banks have identified for the adaption and development of IBS. Education and security were highlighted as the major challenging factors. Customer's education level, their knowledge about the computer and internet were also the prime challenges faced by the bank for the adaptation of internet banking as four out of five of the above mention BFIs have identified it as the major challenges. Similarly, internet security, customer concerned about their private information, theft or loss of password, and internet infrastructure in the country were other major obstacles faced by the bank regarding the development of their online facilities. Trust on internet banking, electricity problem, and training about internet banking to customers were also other concerns for the adaptation and development of internet banking in the country. 

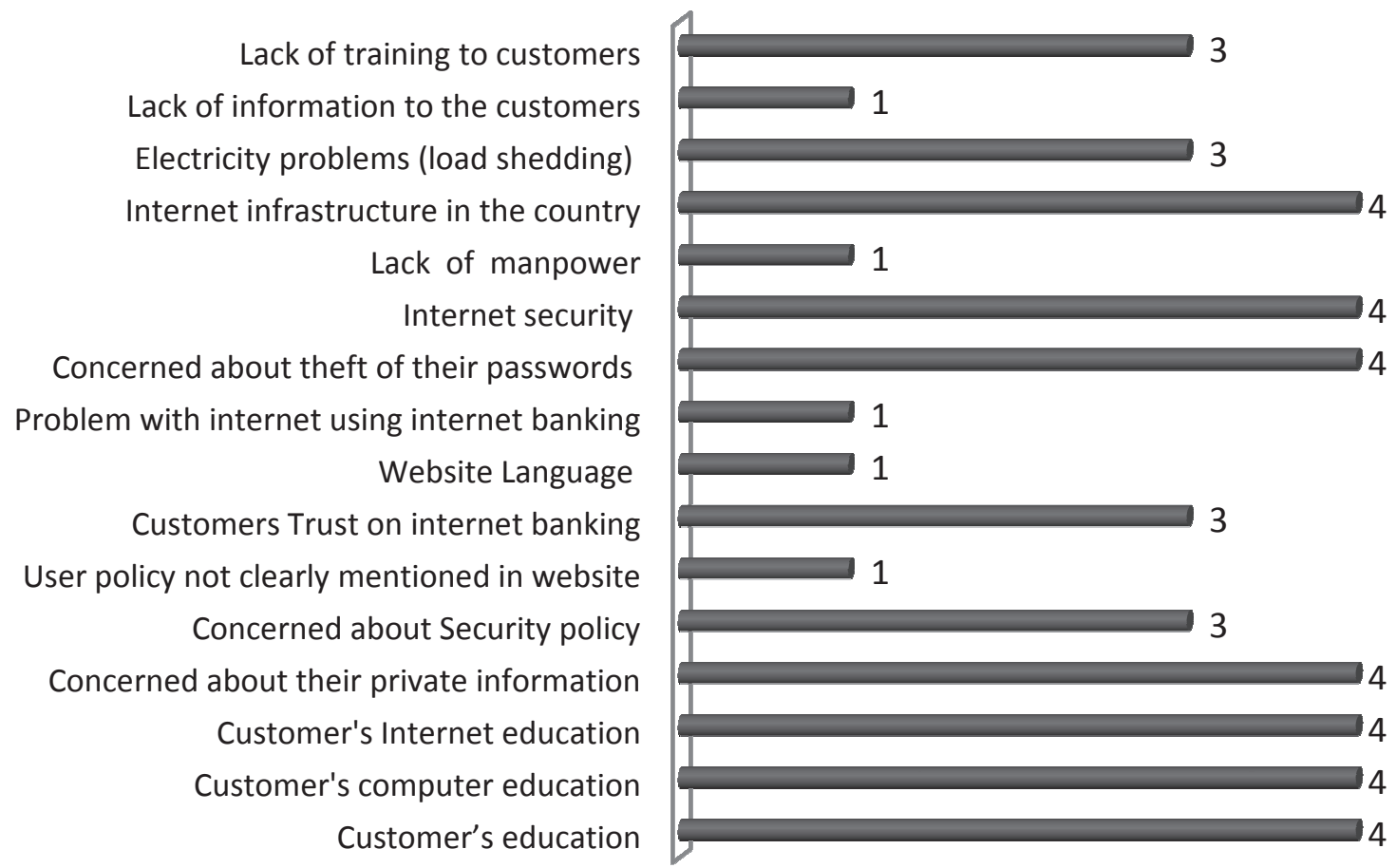

Figure 9: Challenges identified for adaption and development of IBS

\section{DISCUSSION}

It has been found that internet banking services in Nepal is still in its primary stage. Although the sample size chosen in the above study is small but still, this study helps to know about the stage of internet banking and its usage levels and behavior about the customers and the banks itself.

From this study, it could be said that the many of the account holders are using the internet, have some knowledge about the internet banking provided by their bank, but have not developed the habit of utilizing this facility. There are two reasons behind it: first the concern about the security and second the awareness about this facility and its benefits. Again, the facilities or the services thats bank provide through internet banking service is limited and unattractive even to the customers using it.

The low percentage of respondent using internet banking in our study shows that the respondents lacks the information about the internet banking and are also unfamiliar about the online banking technology. Lack of awareness of internet banking services and its benefits are found to be primary reasons for customers' reluctance to use this service. Knowledge and familiarity about the online banking technology and convenience in using it could be the main motivator for customers to use internet banking. Pikkarainen (2004) has reported that the amount of information a customer has about internet banking and its benefit may have a critical impact on the adoption of this service. In our study, although the customers have knowledge about facilities, but the amount of knowledge that they have is not sufficient to jump from the traditional method of banking to an entirely new approach. In addition to awareness, concerns about internet security, privacy, and 
trust have also been noted for the lower rate of acceptance and adaption of internet banking.

Age and sex may also be another factor in our study for the lower adaption of internet banking because some studies revealed that younger customers are more comfortable in using e-banking (Barnett, 1998). Males are more likely to adopt internet banking than females (Katz and Aspden, 1997). Mean age of our respondent was 31 years and in terms of using the facility male percentage was higher than female. Other factors related to less utilization in context to Nepal are electricity problem, the quality and reliability of the internet, trust and reliability on the website, and theft/loss of password.

On the other hand, banks are not informing properly as well as not motivating their customers for using internet banking facilities. Bank should not only just provide the general information about their online facilities but should also explain and educate their customers about the security policies, risk and benefits of using it, and should develop a strategy to motivate current non-users. There were ranges of influential factors that may be modulated in their (customers') behavior of using this facility. The findings also highlighted risk acceptance by customers in regard to internetbased services and the importance of offering deep levels of consumer support for such services.

As more and more BFIs implement internet banking services, it is of paramount importance for these institutions to identify factors that influence customer behavior towards internet banking. From the bankers' prospective the customer's knowledge, internet security, infrastructure, customer trust, privacy, and awareness are being identified as most important challenges for the development of internet banking. Electricity problem and trainings to customers are recognized as other important challenges. Problem with internet while using service, website language and information about the facilities, etc are also identified as factors affecting IBS use, although with less importance. Studies from Gupta (2000), Aladwani (2001), and Hwang et al. (2003) have also identified internet security and customer related issues as challenges of extreme importance compared to the challenges related to technical issues.

In this study, it has been observed that consumer perceptions of online service and factors affecting the adoption of these services have been linked to the information and type of service provided by the bank. So it could be inferred that the guidance and persuasion by bankers does promote the use of such services amongst the customers. The findings of this research however cannot solely portray the overall population as a small size of samples and specific sector was chosen for this research. Again, only a few banks were selected and a detailed scenario could not be presented.

\section{CONCLUSION}

This study reveals that limited services are provided by the BFIs through internet banking facilities. For instance: obtaining the account information, statement and paying the utility bills are main component included in their internet banking 
services. Besides, this study also highlighted the challenges faced by the banks for the development and adaptation of internet banking technology. Mostly customer's knowledge about the internet and its application, awareness, customers concerns about the security, infrastructure, and resources are major barrier faced by the bank for the development and widespread coverage of internet banking technology.

On the other hand, although the customers are aware about the internet banking services but they are not attracted towards utilizing it for their day to day transactions. Banks fail to provide the proper information about the use, benefits, and facilities under internet banking. Security policies, less familiarity towards the technology and its application, etc are some of the major influencing factors regarding the less attraction of the customers on internet banking. Even though the customers enjoying the internet banking facilities are satisfied from the services and have positive attitude towards it, but still a major chunk of population are out of its coverage. Hence, the banks should educate and encourage their customers for using internet banking.

Finally, study suggest that improvements are certainly needed in the internet banking application and environments of use, bank should not merely focus on the adaptation of the new technology but should also focus on encouraging customers towards using the internet banking.

\section{ACKNOWLEDGEMENT}

This research has been partially funded by the Nepal Bankers' Association, Banking Promotion Committee Research Grant, RG\#5(B).

\section{REFERENCES}

Aladwani, A. M. 2001. Online banking: a field study of drivers, development challenges and expectations. International Journal of Information and Management, 2 (1): Pp. 213-225.

Banstola, A. 2007. Prospects and Challenges of E-banking in Nepal. The Journal of Nepalese Business Studies, 4 (1): Pp. 96-104.

Barnett, C. 1998. Virtual Communities and Financial Service: On-Line Business Potentials and Strategies Choice. International Journal of Bank Marketing, 16 (4): Pp. 161-169.

Basel. 1998. Risk Management for Electronic Banking and Electronic Money Activities. Basel Committee Report on Banking Supervision, Bank of International Settlements, Switzerland.

Baten, M. A. 2010. E-Banking of economical prospects in Bangladesh. Journal of Internet Banking and Commerce, 3 (1): Pp. 1-5.

Daniel, E. 1998 Online Banking: Winning the Majority, Journal of financial services Marketing, 2 (3) ): Pp. 259-270.

Gupta, U. 2000. Information Systems: Success in the 21st Century, Upper Saddle River. Prentice-Hall, NJ, United States of America.

Hwang, J. J., T. C. Yeh, and J. B. Li. 2003. Securing on-line credit payment without disclosing privacy information. Computer Standards and Interfaces, 25: Pp. 119-129. 
Katz, J. and P. Aspden. 1997. Motivations for and Barriers to Internet Usage: Results of a National Public Opinion Survey. Internet Research, 7 (3): Pp. 170-188.

Kolodinsky, J. and J. M. Hogarth. 2001. The adoption of electronic banking technologies by American customers. Consumer Interests Annual, 47 (3): Pp. 1-9.

Mishra, B. B. 2008. The Development of E-Payment and Challenges in Nepal. http://www.seacen.org/GUI/pdf/publications/research_proj/2008/rp71/Cha p6.pdf (Accessed on: April 13, 2013).

Mols, N. P. 1999. The Internet and Banks' Strategic Distribution Channel Decision. International Journal of Bank Marketing, 17 (6): Pp. 295-300.

Pikkarainen, T., K. Pijjarainen, H. Karjaluoto, and S. Pahnila. 2004. Consumer acceptance of online banking: an extension of the technology acceptance model. Internet research, 14 (3): Pp. 224-235.

Rubino, G. 2000. Getting and Keeping Online Customers: If You Build it, Will They Come? Bank Marketing, 32 (3): Pp. 36-40.

Sharma, H. 2011. Bankers' Perspective on E-Banking. National Journal of Research in Management, 1 (1): Pp. 71-85.

Turban, E., J. Lee, D. King, and H. M. Chung. 2000. Electronic Commerce: A Managerial Perspective. Upper Saddle River, Prentice Hall, NJ, USA. 


\section{ANNEXES}

\section{Annex 1}

Research Questionnaire for Internet Banking in Nepal

(Question to be answered by representative of Banks and Financial Institutions)

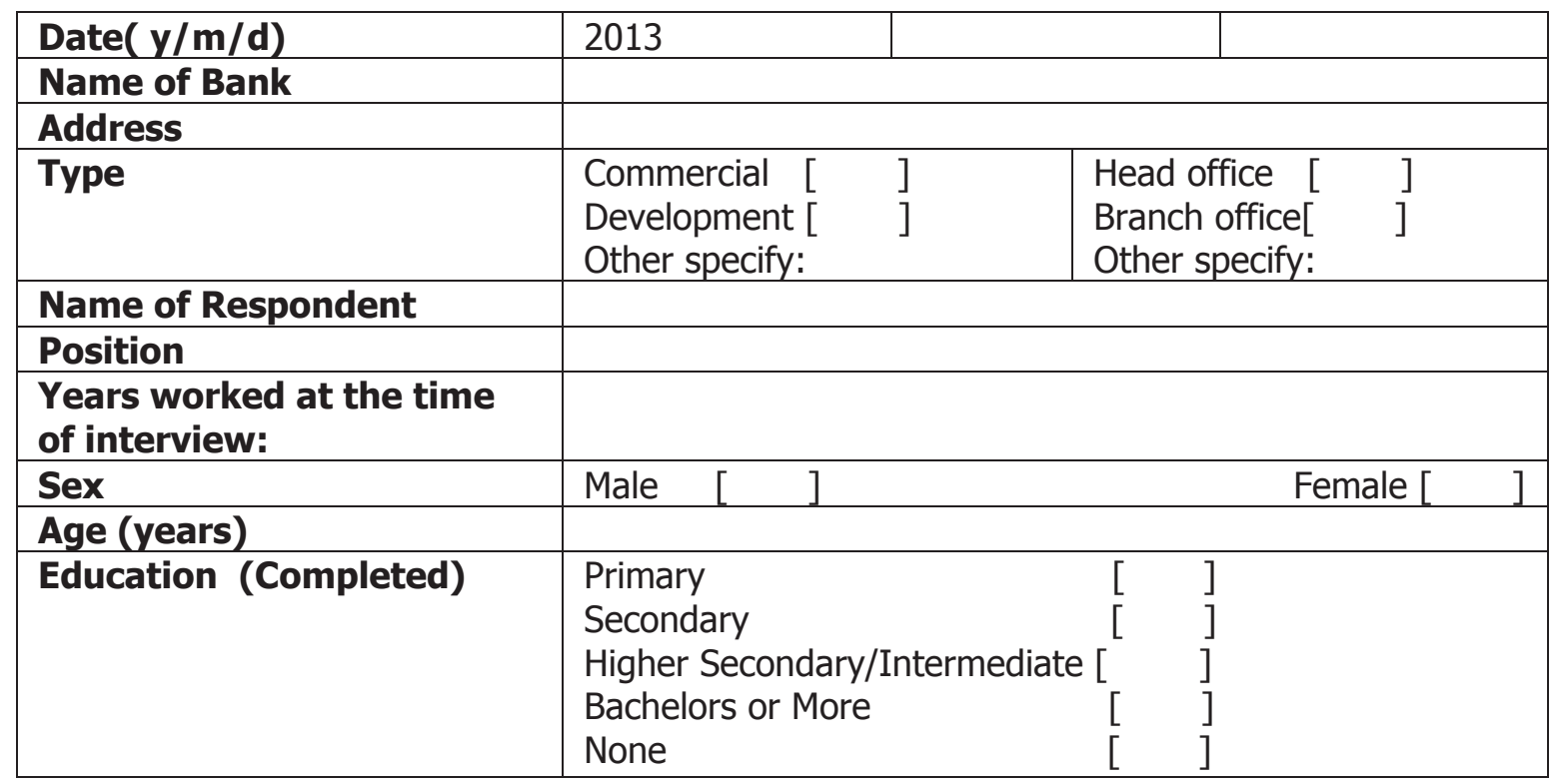

\begin{tabular}{|c|c|c|c|c|c|}
\hline \multicolumn{3}{|c|}{ General question } & \multicolumn{3}{|c|}{ Pleases tick $\square$ in the respective brackets } \\
\hline 1 & \multicolumn{2}{|c|}{$\begin{array}{l}\text { Does bank provide any internet } \\
\text { banking services? }\end{array}$} & \multicolumn{3}{|c|}{ 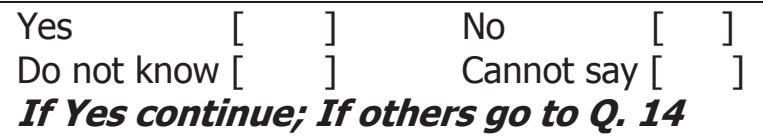 } \\
\hline 2 & \multicolumn{5}{|c|}{$\begin{array}{l}\text { What kinds of internet banking services are provided by your bank? } \\
\text { (Pleases tick } \square \text { in the respective brackets) }\end{array}$} \\
\hline \multicolumn{2}{|c|}{ Account Services } & \multicolumn{2}{|c|}{ Fund Transfer } & & edit Card Management \\
\hline \multicolumn{2}{|c|}{ Account information } & \multicolumn{2}{|c|}{$\begin{array}{l}\text { Within same bank } \\
\text { accounts }\end{array}$} & & Credit card transaction review \\
\hline \multicolumn{2}{|c|}{$\begin{array}{l}\text { Request for statement } \\
\text { (view) }\end{array}$} & \multicolumn{2}{|c|}{$\begin{array}{l}\text { To other bank } \\
\text { accounts within Nepal }\end{array}$} & & Credit card payments \\
\hline \multicolumn{2}{|c|}{$\begin{array}{l}\text { Download and print } \\
\text { statements }\end{array}$} & \multicolumn{2}{|c|}{ Personal Updates } & & $\begin{array}{l}\text { Credit card limit increase } \\
\text { request }\end{array}$ \\
\hline \multicolumn{2}{|c|}{ Cheque book request } & \multicolumn{2}{|c|}{ Change contact details } & & Utility Purpose \\
\hline \multicolumn{2}{|c|}{$\begin{array}{l}\text { Status of inward } \\
\text { remittance }\end{array}$} & \multicolumn{2}{|c|}{$\begin{array}{l}\text { Change address } \\
\text { information }\end{array}$} & & Paying utility bills \\
\hline \multicolumn{2}{|c|}{ Others Specify: } & & & & Investment purpose \\
\hline
\end{tabular}




\begin{tabular}{|c|c|c|}
\hline 3 & $\begin{array}{l}\text { For what kind of customers bank } \\
\text { provide the internet banking } \\
\text { facilities? }\end{array}$ & $\begin{array}{lll}\text { All } & {[} & \text { Corporate [ ] } \\
\text { Foreigners [ } & ] & \text { Don't know [ ] } \\
\text { Cannot say [ } & \text { Others (specify): }\end{array}$ \\
\hline 4 & $\begin{array}{l}\text { When was the first internet banking } \\
\text { service operated by the bank? }\end{array}$ & $\begin{array}{l}\text { (YY/MM/DD): } \\
\text { Cannot say }[\quad]\end{array}$ \\
\hline 5 & $\begin{array}{l}\text { Is there any specific time allocated } \\
\text { for the internet banking services? }\end{array}$ & 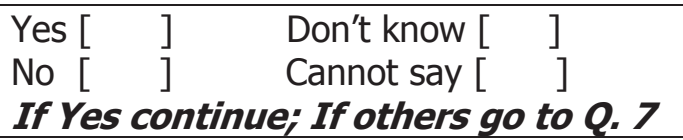 \\
\hline 6 & When? & 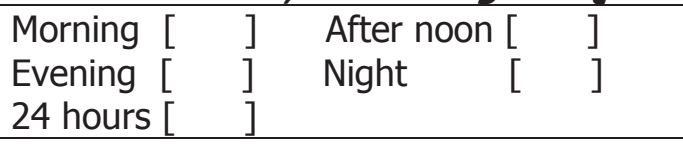 \\
\hline 7 & $\begin{array}{l}\text { Do customers get access to internet } \\
\text { banking services as soon as they } \\
\text { open the account in the bank? }\end{array}$ & 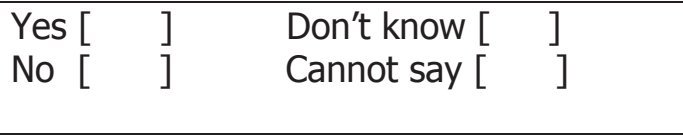 \\
\hline 8 & $\begin{array}{l}\text { Do customers have to register for } \\
\text { utilizing the internet banking } \\
\text { services of the bank? }\end{array}$ & $\left.\begin{array}{lll}\text { Yes [ } & ] & \text { Don't know [ } \\
\text { No [ } & ] & \text { Cannot say [ }\end{array}\right]$ \\
\hline 9 & $\begin{array}{l}\text { Is there any registration fee for } \\
\text { utilizing the internet banking } \\
\text { services? }\end{array}$ & 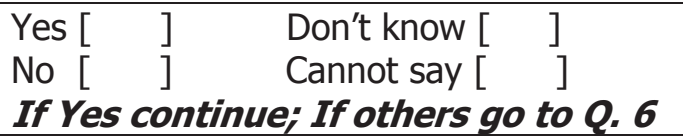 \\
\hline 10 & $\begin{array}{l}\text { How much they have to pay for } \\
\text { registration? }\end{array}$ & 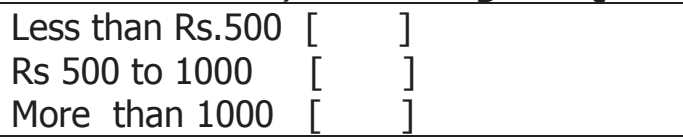 \\
\hline 11 & $\begin{array}{l}\text { Do customers have to pay for } \\
\text { utilizing the internet banking } \\
\text { services? }\end{array}$ & $\begin{array}{ll}\text { Yes }\left[\begin{array}{ll}{[} & \text { Don't know [ }\end{array}\right] \\
\text { No [ } \quad] \quad \text { Cannot say [ ] } \\
\text { If Yes continue; If others go to } \boldsymbol{Q} . \mathbf{1 1}\end{array}$ \\
\hline 12 & On what basis & 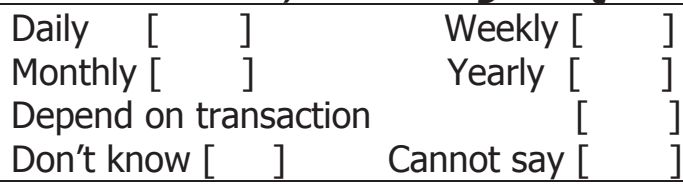 \\
\hline 13 & How much customers have to pay? & $\begin{array}{l}\text { Less than Rs.500 } \\
\text { Rs } 500 \text { to } 1000 \\
\text { More than } 1000\end{array}$ \\
\hline
\end{tabular}




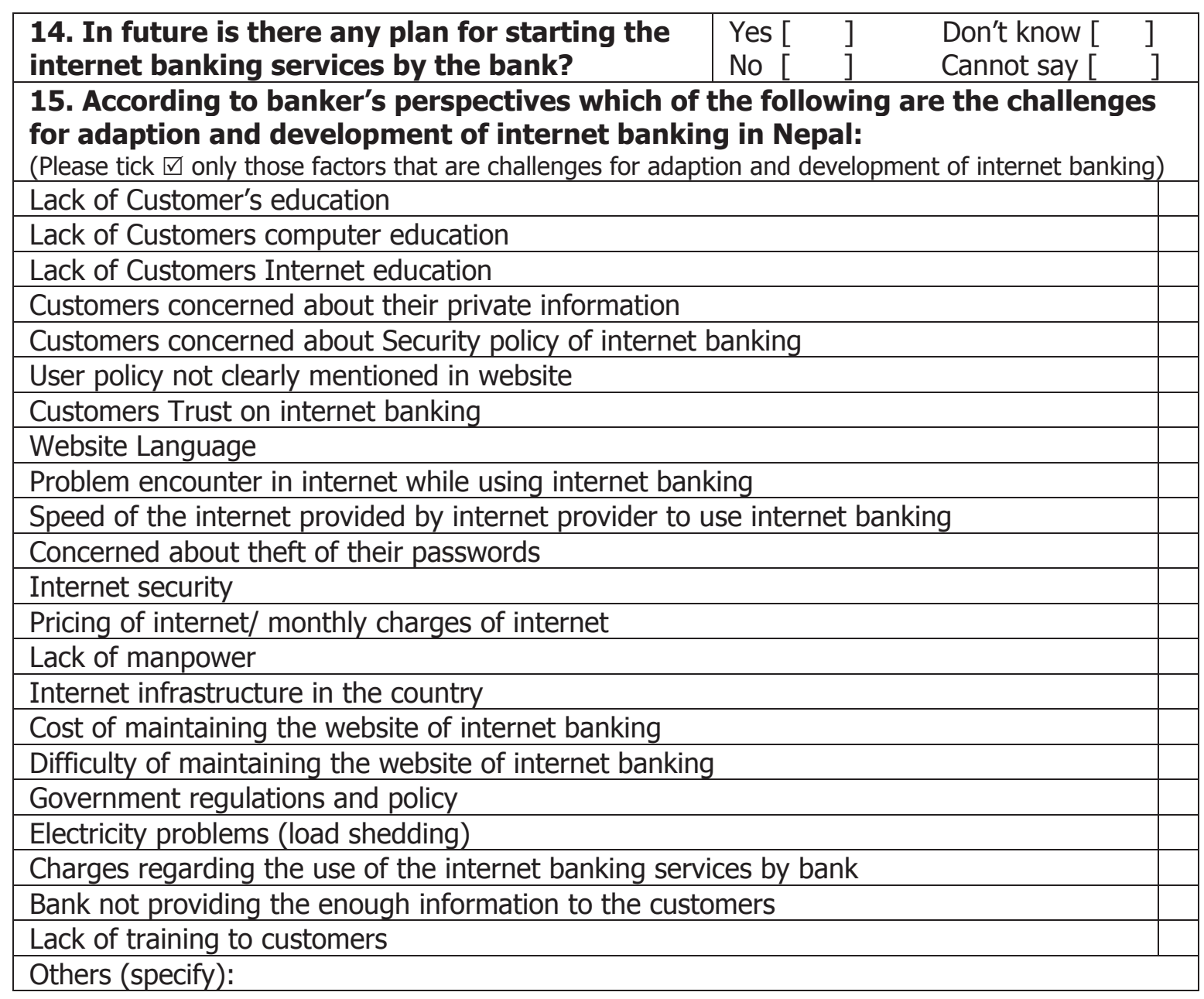




\section{Annex 2}

Research questionnaire for internet banking in Nepal

(Question to be answered by the individual respondent)

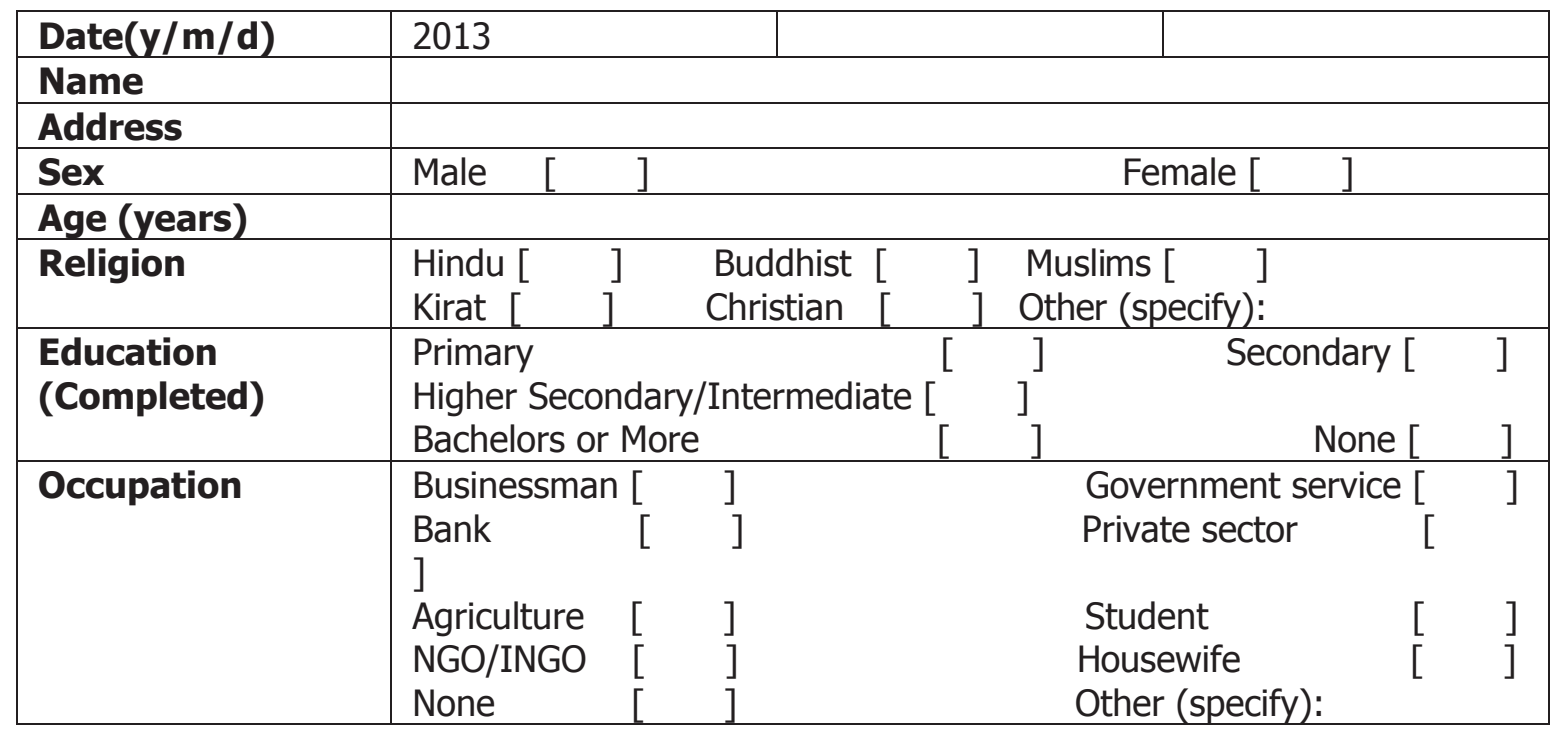

\begin{tabular}{|c|c|c|}
\hline 1 & Do you have bank account? & $\begin{array}{l}\text { Don't know [ } \\
\text { Cannot say [ }\end{array}$ \\
\hline 2 & $\begin{array}{l}\text { Name the bank that you hold } \\
\text { the account: }\end{array}$ & $\begin{array}{ll}\text { 1) } & \text { 2) } \\
\text { Cannot say }[\quad] & \end{array}$ \\
\hline 3 & $\begin{array}{l}\text { Have you heard about Internet } \\
\text { banking? }\end{array}$ & 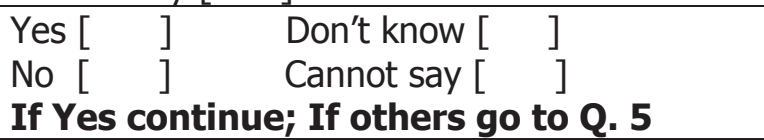 \\
\hline 4 & What is the source? & $\begin{array}{ll}\text { Bank itself [ }] & \text { IBS user [ } \\
\text { Media (TV/radio/Newspaper) [ } & ] \\
\text { Others (specify): } & \end{array}$ \\
\hline 5 & Do you use internet? & 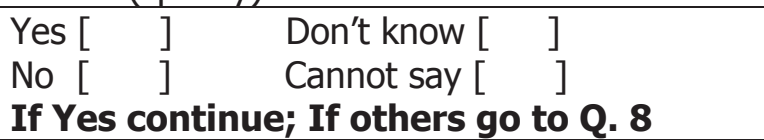 \\
\hline 6 & $\begin{array}{l}\text { Where do you have internet } \\
\text { connections? }\end{array}$ & 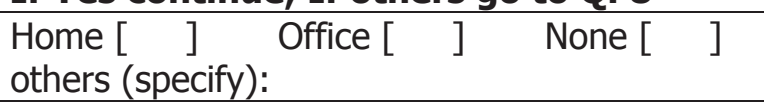 \\
\hline 7 & $\begin{array}{l}\text { What type of internet service you } \\
\text { have? }\end{array}$ & 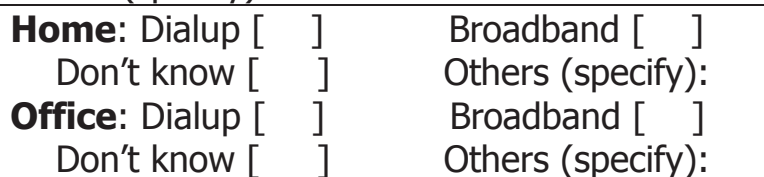 \\
\hline 8 & $\begin{array}{l}\text { Does your bank provide internet } \\
\text { banking services? }\end{array}$ & $\begin{array}{l}\text { Don't know [ } \\
\text { Cannot say [ }\end{array}$ \\
\hline 9 & $\begin{array}{l}\text { Have you ever visited your bank } \\
\text { website? }\end{array}$ & $\begin{array}{l}\text { Don't know [ } \\
\text { Cannot say [ }\end{array}$ \\
\hline 10 & $\begin{array}{l}\text { Have you ever used/using } \\
\text { internet banking services? }\end{array}$ & 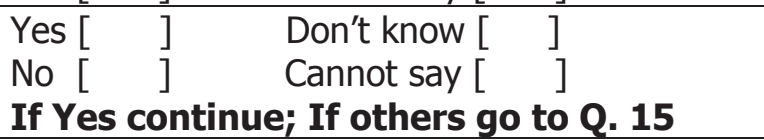 \\
\hline 11 & $\begin{array}{l}\text { How often do you use internet } \\
\text { banking services? }\end{array}$ & $\begin{array}{l}\text { Daily [ ] Weekly [ ] } \quad \text { Monthly [ ] } \\
\text { Others (specify): }\end{array}$ \\
\hline
\end{tabular}




\begin{tabular}{|c|c|c|c|c|c|c|c|}
\hline 12 & \multirow{2}{*}{\multicolumn{2}{|c|}{$\begin{array}{l}\text { For what purpose you use the } \\
\text { internet banking services? } \\
\text { Where have you used/using the } \\
\text { internet banking services? }\end{array}$}} & $\begin{array}{l}\text { Personal [ } \\
\text { Official }[\end{array}$ & & \multicolumn{3}{|c|}{$\begin{array}{l}\text { Business [ ] } \\
\text { Others (specify): }\end{array}$} \\
\hline 13 & & & $\begin{array}{l}\text { Within Nepal [ ] } \\
\text { Others (specify): }\end{array}$ & \multicolumn{4}{|c|}{ Outside Nepal [ ] } \\
\hline \multicolumn{8}{|c|}{$\begin{array}{l}\text { 14. Which of the below given activities you do from internet banking? } \\
\text { (Only for those who have used/ using internet banking services) Please tick } \square\end{array}$} \\
\hline \multicolumn{2}{|c|}{ Account Services } & \multicolumn{2}{|c|}{ Fund Transfer } & \multicolumn{4}{|c|}{ Utility Purpose } \\
\hline \multicolumn{2}{|c|}{ Account information } & \multicolumn{2}{|c|}{ Within same bank accounts } & & \multicolumn{3}{|c|}{ Paying utility bills } \\
\hline \multicolumn{2}{|c|}{ Request for statement (view) } & \multicolumn{2}{|c|}{$\begin{array}{l}\text { To other bank accounts } \\
\text { within Nepal }\end{array}$} & \multicolumn{4}{|c|}{ Investment purpose } \\
\hline \multicolumn{2}{|c|}{$\begin{array}{l}\text { Download and print } \\
\text { statements }\end{array}$} & \multicolumn{2}{|c|}{ Personal Updates } & \multicolumn{4}{|c|}{ Others Specify: } \\
\hline \multicolumn{2}{|c|}{ Cheque book request } & \multicolumn{2}{|c|}{ Change contact details } & \multicolumn{3}{|c|}{1.} & 2. \\
\hline \multicolumn{2}{|c|}{ Status of inward remittance } & \multicolumn{2}{|c|}{$\begin{array}{l}\text { Change address } \\
\text { information }\end{array}$} & \multicolumn{3}{|c|}{3.} & 4. \\
\hline \multicolumn{8}{|c|}{ Now go to 0.17} \\
\hline \multicolumn{6}{|c|}{ 15. What are the factors for not using internet banking services? } & \multicolumn{2}{|c|}{ Please tick $\square$} \\
\hline \multicolumn{8}{|c|}{ Lack of information about internet banking. } \\
\hline \multicolumn{8}{|c|}{ Concerned about security policies of Internet banking. } \\
\hline Int & net banking site is not tru & rthy. & & & & & \\
\hline Int & net banking is not trustwo & & & & & & \\
\hline Not & Access to computers. & & & & & & \\
\hline Lac & of familiarity with comput & & & & & & \\
\hline Lac & of familiarity with online $b$ & ng tech & logy. & & & & \\
\hline Lac & of familiarity with internet & & & & & & \\
\hline Diff & ulty in understanding and & onlin & anking facilities. & & & & \\
\hline Unf & endly web site design. & & & & & & \\
\hline Cor & erns about speed and/or & lity of $t$ & hnology. & & & & \\
\hline Ele & ricity problem. & & & & & & \\
\hline Lac & of regular banking activiti & & & & & & \\
\hline If 0 & ner specify: & & & & & & \\
\hline & $\begin{array}{l}\text { How aware are you abc } \\
\text { its benefits? }\end{array}$ & he inte & et banking servic & & & ee & Disagree \\
\hline I re & eive enough information a & Interne & anking services & & & & \\
\hline I re & eive enough information a & the ber & its of Internet bankir & & & & \\
\hline I re & eive enough information a & how to & Internet banking & & & & \\
\hline & er received information at & Interne & anking from the ban & & & & \\
\hline & fer traditional method of & $\mathrm{ng}$ than & ternet banking & & & & \\
\hline & $\begin{array}{l}\text { fer to use internet bankin } \\
\text { mation/training is provides }\end{array}$ & vices $w h$ & enough & & & & \\
\hline
\end{tabular}


Following questions are only for those WHO HAVE USED OR USING internet banking facilities.

\begin{tabular}{|l|l|}
\hline $\begin{array}{l}\text { 17. How you perceive about using internet banking? } \\
\text { (please ranke from Strongly Agree - Agree - Moderate - Disagree - Strongly Disagree) }\end{array}$ \\
\hline Internet banking enables me to accomplish banking activities more quickly. & \\
\hline Internet banking enables me to accomplish more banking activities. & \\
\hline Internet banking gives me greater control over financial banking activities. & \\
\hline The security of Internet banking is important. & \\
\hline The security policies of Internet banking are available to customers. & \\
\hline Using internet to do money transaction is secure. & \\
\hline I would feel secure sending sensitive information over the internet. & \\
\hline My access to the Internet is easy. & \\
\hline Using the Internet for handling online financial transactions is efficient. & \\
\hline The Internet enables customers to access the bank's website 7/24. & \\
\hline The Internet banking website is trustworthy. & \\
\hline The Internet banking website keeps its promises and commitments. & \\
\hline The Internet banking website keeps customers' best interest in mind. & \\
\hline I trust my bank's Internet banking website. & \\
\hline Interaction with Internet banking site is clear and understandable. & \\
\hline It is easy to do what I want to do using Internet banking. & \\
\hline Learning to use Internet banking will be or has been easy. & \\
\hline Overall, I expect Internet banking will be easy for me to use. & \\
\hline Internet banking development will support customers. & \\
\hline I will encourage the use of Internet banking among my colleagues. & \\
\hline I am not satisfied with using traditional banking services when carrying out financial \\
activities.
\end{tabular}

